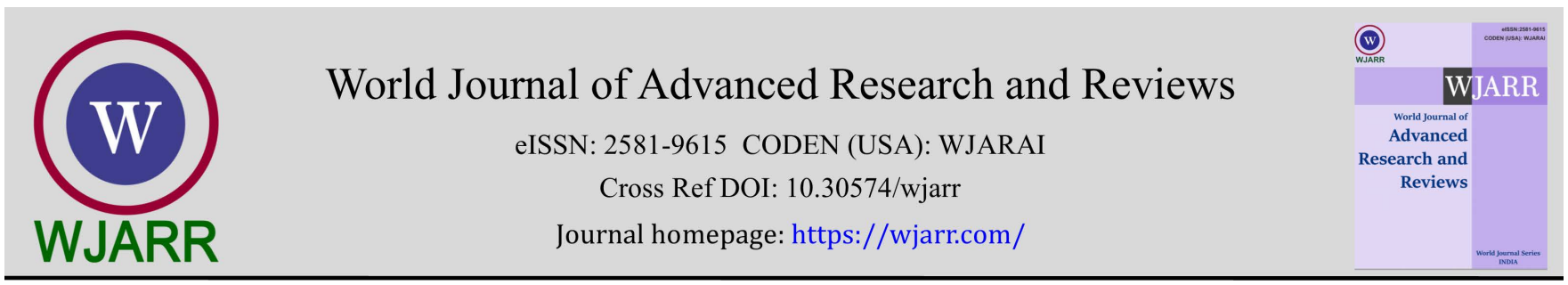

(RESEARCH ARTICLE)

Check for updates

\title{
Co-treatment of cotton (Gossypium hirsutum var R405 2000) with methyl jasmonate and ethephon: Impact on the production of phenolic compounds
}

\author{
Yao Kouakou François KONAN 1,* , Manéhonon Martine BEUGRÉ ${ }^{1}$, Sopie Edwige Salomé YAPO ${ }^{1}$ and Hilaire \\ Tanoh KOUAKOU 2 \\ ${ }^{1}$ UFR Agroforesterie, Université Jean Lorougnon Guédé. BP 150 Daloa, Côte d'Ivoire. \\ ${ }^{2}$ UFR SN, Laboratoire de Biologie et Amélioration de Productions Végétales, Université Nangui Abrogoua, 02 BP 801 \\ Abidjan 02, Côte d'Ivoire.
}

World Journal of Advanced Research and Reviews, 2021, 11(03), 234-241

Publication history: Received on 30 July 2021; revised on 16 September 2021; accepted on 18 September 2021

Article DOI: https://doi.org/10.30574/wjarr.2021.11.3.0420

\begin{abstract}
The objective of this study is to show the real impact of methyl jasmonate and ethephon in combination on the production of phenolic compounds in cultivar R405-2000 of the cotton plant Gossypium hirsutum. As well, cotton plants were treated in the field by methyl jasmonate (MeJA), ethephon (ETH) and the association of methyl jasmonate and ethephon (MeJA + ETH). The effect of these treatments was appreciated thanks to a qualitative analysis of total phenols by High Performance Liquid Chromatography. The results showed that ethephon, the metabolic precursor of ethylene, has properties identical to those of MeJA. However, the treatment of cotton leaves with ethephon induces less phenolic compounds than MeJA. On the other hand, the co-treatment of the leaves with MeJA and ethephon leads to an induction of phenolic compounds, which accumulate in greater quantities in the plant the phenols synthesized are more important with an activation of the biosynthetic pathway of stilbenoids because trans-resveratrol and transpiceide, two compounds belonging to the group of stilbenoids were synthesized de novo by the joint application of MeJA and ethephon on cotton leaves when they could not be synthesized when these two elicitors are applied alone.
\end{abstract}

Keywords: Methyl jasmonate; Phenolic compounds; Ethephon; Cotton; Stilbenoids; Gossypium hirsutum

\section{Introduction}

Cotton is a textile and protea-oleaginous plant to multiple use. [1]. It is therefore a very important source of currency for the economy of several countries. Cotton represents the main raw material of the textile industries and the seeds rich in oil and proteins are used in human and animal food [1]. However, the cotton plant is threatened by parasites and various diseases which reduce production, the quality of fibers and seeds [2]. However, studies have shown that in front of aggression by pathogens, plants produce secondary metabolites, in particular phenolic compounds, to defend themselves [3]. Thus, cotton produces a large number of phenolic compounds which are decisive in resistance to diseases [4]. However, some plants remain susceptible to pathogens and the establishment of the disease, more by a slow defense response than by the absence of a defense mechanism [5;6]. As a result, recent studies have proposed the stimulation or induction of these compounds by other compounds called stimulators of natural defenses. Studies have shown that MeJA and ethylene can act synergistically on certain defense genes, thereby leading to an increase in resistance to pathogens $[7 ; 8 ; 4 ; 9]$. The object of this article is to show the qualitative impact of the co-traitment of methyl jasmonate and ethephon on the production of phenolic compounds in cotton sheets.

\footnotetext{
${ }^{*}$ Corresponding author: Yao Kouakou François Konan

UFR Agroforesterie, Université Jean Lorougnon Guédé. BP 150 Daloa, Côte d’Ivoire. 


\section{Material and methods}

\subsection{Plant Material}

The plant material consists of the cotton cultivar R405-2000 (Gossypium hirsutum L.), originating from Côte d'Ivoire. It is an improved cultivar, resulting from the cross between local lines and introduced lines [10]. The seeds come from the Korhogo region (Côte d'Ivoire) and were supplied by the Ivorian Company for Textile Development (ICTD). The cultivar R405-2000 has a very high level of sensitivity to Fusarium oxysporum f. sp. vasinfectum, causative agent of Fusarium wilt [11]

\subsection{Methods}

Cotton plants two months old were used for this study. The plants were produced from cotton seeds. The seeds were first delinted (stripped of their fibers) with concentrated sulfuric acid. They were then sterilized in a laminar flow hood by rapid dipping for one minute in $70 \%$ ethanol (v / v), followed by $20 \mathrm{~min}$ immersion in bleach (2.5\% active chlorine) then rinsed three times with sterile distilled water. Two seeds were placed in a test tube containing $30 \mathrm{ml}$ of sterile distilled water. All was incubated for 48 hours in the dark to facilitate germination. The seeds whose radicle points out after imbibition were placed in $500 \mathrm{ml}$ pots containing soil previously sterilized in an autoclave at $121^{\circ} \mathrm{C}$ for $30 \mathrm{~min}$.

\subsubsection{Treatment of cotton plants with natural defense stimulators}

At the nine to ten spread leaf stage obtained after approximately two months of growing, 60 cotton plants (15 plants / treatment) are sprayed with $5 \mathrm{mM}$ MeJA [4], $5 \mathrm{~g} / \mathrm{l}$ of ethephon [4] and a solution consisting of an equal volume mixture of MeJA (5 mM) and ethephon (5 g / l). MeJA and ethephon were previously dissolved in $1 \%$ ethanol, added to an aqueous solution containing $0.1 \%$ Triton X-100. The latter acts as an adjuvant and allows a longer retention of the product on the leaves while conferring a penetrating power in the leaves. The MeJA and the ethephon were aseptically prepared, under the laminar flow hood, using solvents sterilized by filtration $(0.22 \mu \mathrm{m})$. Each plant received approximately one $10 \mathrm{ml}$ application of each solution using a sprayer. To promote the opening of the stomata, the humidity is maintained at $90 \%$ by spraying water under the enclosure. Cotton plants sprayed with $1 \%$ ethanol, supplemented with $0.1 \%$ Triton X-100 solution, served as controls. After spraying, the incubation time for the cotton plants was $72 \mathrm{~h}$. The leaves are then removed and freeze-dried.

\subsubsection{Qualitative analysis of total phenols by High Performance Liquid Chromatography}

Extraction and purification of phenolic compounds from the leaves

The extraction of total phenols was carried out on dry matter after lyophilization according to the method of kouakou [Reference 12]. After determining the dry matter of each sample, $200 \mathrm{mg}$ of leaves were immersed in $20 \mathrm{ml}$ of methanol and then placed overnight at $4{ }^{\circ} \mathrm{C}$. After centrifugation at $2000 \mathrm{~g}$ for $10 \mathrm{~min}$, the supernatant obtained was filtered through a Millipore membrane $(0.45 \mu \mathrm{m})$ and constituted the raw phenolic extract. For purification, $4 \mathrm{ml}$ of the raw phenolic extract were evaporated with Speed Vac (Savant, USA). The sample was taken up in 1 ml of methanol / water $(30 / 70, v / v)$ and then chromatographed on a mini column of C18 toasted silica (Sep pack®) in the Supelco Visiprep ${ }^{\mathrm{TM}}$ system. Before, the columns were conditioned by successive washing with $100 \%$ methanol ( $2 \mathrm{ml}), 50 \% \mathrm{methanol}$ ( $2 \mathrm{ml})$ and distilled water $(6 \mathrm{ml})$. After depositing the sample, washing with $2 \mathrm{ml}$ of distilled water was carried out, then the phenolic compounds were eluted with $4 \mathrm{ml}$ of methanol / water $(90 / 10, \mathrm{v} / \mathrm{v})$. The eluate obtained was evaporated at Speed Vac, taken up in $1 \mathrm{ml}$ of methanol / water $(50 / 50, \mathrm{v} / \mathrm{v})$ then filtered through a Millipore membrane $(0.45 \mu \mathrm{m})$ before being injected in high performance liquid chromatography (purified phenolic extract).

\section{Analysis conditions}

High Performance Liquid Chromatography (HPLC) was performed according to the modified method of Belhadj et al [reference13]. It has been used for the separation and quantification of the various phenolic compounds in cotton leaves treated with MeJA, ethephon and the MeJA / Ethephon association. The analysis of the samples was carried out on two HPLC chains; the first chain (Agilent LC 1100 series) is equipped with a degasser, an automatic injector, a high-pressure binary pump and a UV-visible detector. The second chain (Agilent LC 1200 series) includes a quaternary pump and is connected to an iodine bar detector and a nuclear magnetic resonance spectrometer (Bruker Avance III, 600 MHZ). The column used with the two chains is a reverse phase C18 (Prontosil, $250 \times 4.0 \mathrm{~mm}, 5 \mu \mathrm{m}$, Bischoff). Elution was carried out with a binary gradient composed of: - solvent A: trifluoroacetic acid (TFA) 1\% / water (2.5 / 97.5, v / v) - solvent B: acetonitrile / solvent A ( 80 / 20, v / v). The profile of the elution gradient is presented in the table below. The chromatograms were detected at $284 \mathrm{~nm}$, with a flow rate of $0.8 \mathrm{ml} / \mathrm{min}$. The phenolic compounds used in this study were selected based on their commercial availability and their possible presence in cotton [14; 15; 16]. These phenolic 
compounds are as follows: astringine, picideide, piceatannol, pterostilbene and resveratrol, gallic acid, caffeic acid, chlorogenic acid, ferulic acid, p-coumaric acid, salicylic acid, trans-cinnamic acid, catechin, epicatechin, genistein, gossypine, naringenin, quercetin, quercitin and rutin.

Table I Elution gradient of Phenolic compounds in HPLC

\begin{tabular}{|l|c|c|}
\hline \multicolumn{1}{|c|}{ Time (min) } & Solvent (A) & Solvent (B) \\
\hline 0 & 90 & 10 \\
\hline $0-40$ & 90 & 10 \\
\hline $40-41$ & 50 & 50 \\
\hline $41-50$ & 0 & 100 \\
\hline $50-51$ & 90 & 10 \\
\hline $51-70$ & 90 & 10 \\
\hline
\end{tabular}

HPLC: high performance liquid chromatography; solvent A: 1\% trifluoroacetic acid (TFA) / water (2.5 / 97.5, v / v); solvent B: acetonitrile / solvent $\mathrm{A}(80 / 20, \mathrm{v} / \mathrm{v})$.

HPLC determination of phenolic compounds in leaves

The separation and the determination of the phenolic compounds were carried out in HPLC under a pressure of 170 to 400 bars. Ten (10) $\mu \mathrm{l}$ of the hydromethanolic extract was directly injected and the chromatograms were detected using a Prostar iodine bar detector (model 335) at $284 \mathrm{~nm}$. Each analysis was repeated three times. A reference library of phenolic compounds is produced previously with purified compounds identified by nuclear magnetic resonance (NMR) and also with commercially available compounds. This library contains the retention times and the NMR spectra of these compounds. The chromatograms obtained were identified by comparison with those obtained from the samples injected. The structure of the phenolic compounds is verified by NMR. The phenol content of the leaves is calculated relative to calibration curves carried out with pure compounds isolated from the samples or those obtained commercially. The capture of the chromatograms and the control of the HPLC are managed by microcomputer (Workstation system).

\subsection{Statistical analysis}

Statistical analysis were performed using SAS 6.0 software. An analysis of variance (ANOVA) was performed on all the treatments applied. When this analysis shows a difference between the means, the Duncan's test is performed in order to determine the significant differences between the treatments at the $5 \%$ threshold. For percentages, the KruskalWallis test was used to determine the significant differences $(\mathrm{P}<0.05)$ between treatments.

\section{Results and discussion}

Phenolic compounds identified in the leaves treated with MeJA, ethephon and the MeJA / Ethéphon association

Chromatographic analysis of cotton leaves treated with ethephon revealed the presence of seven compounds which are gossypol, cafféol-D-glucose, catechin, 3-p-coumaroylquinic acid, ferulic acid, gossypetine and chlorogenic acid. Compared to the chromatographic profile of cotton leaves treated with MeJA, we observe the disappearance of stilbenes (trans-piceatannol and trans-pterosilbene) and chicoric acid (Figure 1). This result shows that the application of ethylene in the form of an ethephon mobilizes fewer phenolic compounds than MeJA. Indeed, the accumulation of phenolic phytoalexins in plants has been reported as a potential activator of plant defense because it has allowed resistance against fungal attacks to be induced $[17 ; 18]$. Thus, the weak biosynthesis of phenolic compounds would indicate a weak activation of the cotton's natural defenses by ethylene. However, the work of Diaz et al [Reference19] have shown that ethylene stimulates the natural defenses of tomatoes by inducing resistance to Botrytis cinerea as well as those of Belhadj et al [Reference 20] on the vine by inducing protection against Erysiphe necator. This result shows that the action of ethylene on the production of phenolic phytoalexins which stimulate natural defenses is dependent on the variety of plant used. In addition, gossypol, catechin and chlorogenic acid were 3 times higher with ethylene than with MeJA. 


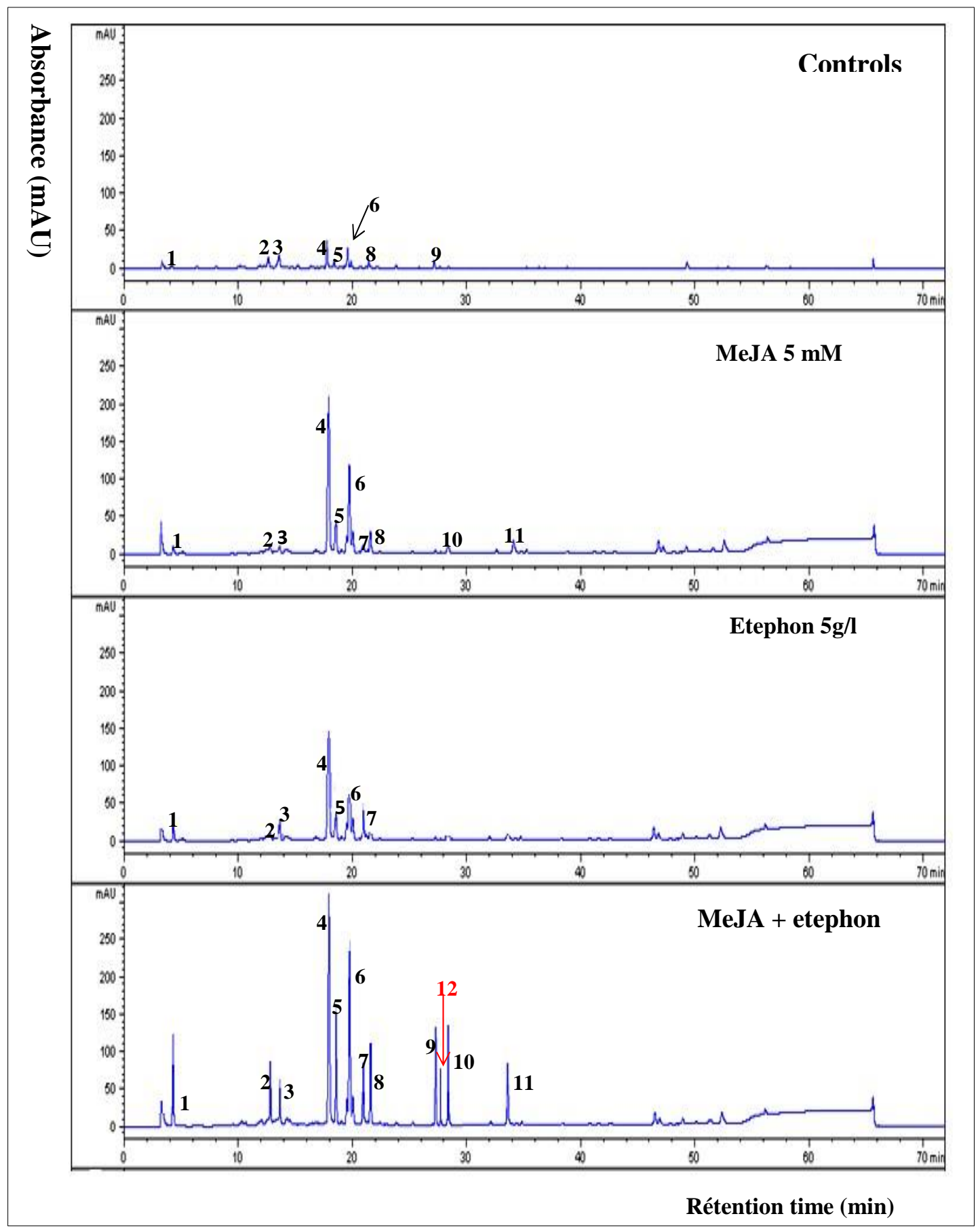

Figure 1 Chromatograms of phenolic compounds extracted from cotton leaves treated with MeJA, ethephon and addition of MeJA / ethephon at $284 \mathrm{~nm}$

1. Gossypol (4.237 min); 2. Caffeyol-D-glucose (12.770 min); 3. Catechin (13.597 min); 4. 3-p- acidcoumaroylquinique (17.895 min); 5. Ferulic acid (18.524 min); 6. Gossypetine (19.704 min); 7. Chlorogenic acid (20.995 min); 8 transPiceatannol (21.545 min); 9. trans-Resveratrol (26.993 min); 10. trans-Pterosilbene (28.344 min); 11. Chicoric acid (34.083 min); 12. trans-Picideide (27,864 min); MeJA: methyl jasmonate.

On the other hand, the contents of ferulic acid and caffeeyol-D-glucose remained identical regardless of the elicitor used (Table 2). These results suggest that the ethephon acts by promoting the accumulation of certain phenolic compounds. The ethephon is said to act by activating enzymes belonging to different biosynthetic pathways than those of MeJA. Thus, the biosynthetic pathways of gossypol, catechin and chlorogenic acid would be activated via the PAL [21; 22]. Taking into account phenolic groups, ethylene promotes the accumulation of terpenoids which induce resistance against pathogens $[23 ; 24]$. 
Table 2 Content of phenolic compounds extracted from cotton leaves treated with ethephon and co-treatment with MeJA and ethephon

\begin{tabular}{|c|c|c|c|c|c|}
\hline \multirow{2}{*}{ Phenolic group } & \multirow[b]{2}{*}{$\begin{array}{l}\text { Phenolic } \\
\text { compounds }\end{array}$} & \multirow[b]{2}{*}{$\begin{array}{l}\text { Control } \\
\text { not traited }\end{array}$} & \multicolumn{2}{|c|}{ Content ( $\mu g$ / g) } & \multirow[b]{2}{*}{$\begin{array}{l}\text { Cotraitement } \\
\text { MeJA/etephon }\end{array}$} \\
\hline & & & MeJA (5mM) & $\begin{array}{l}\text { Etephon } \\
(5 \mathrm{~g} / \mathrm{l})\end{array}$ & \\
\hline \multirow{4}{*}{ Stilbenoids } & Pterostilbene & nd & $2.19 \pm 0.01^{\mathrm{a}}$ & nd & $35.57 \pm 0.34^{c}$ \\
\hline & $\begin{array}{l}\text { trans- } \\
\text { Resveratrol }\end{array}$ & $1.85 \pm 0.01^{\mathrm{b}}$ & nd & nd & $2.94 \pm 0.08^{a}$ \\
\hline & trans-Piceatannol & $2.11 \pm 0.01^{\mathrm{a}}$ & $8.35 \pm 0.15^{d}$ & nd & $33.16 \pm 0.65^{c}$ \\
\hline & trans-Piceide & nd & nd & nd & $11.93 \pm 0.45^{b}$ \\
\hline \multirow{3}{*}{$\begin{array}{l}\text { Hydroxycinnamic } \\
\text { acids }\end{array}$} & Chicoric acid & nd & $3.47 \pm 0.01^{\mathrm{f}}$ & nd & $17.25 \pm 0.32^{\mathrm{e}}$ \\
\hline & Ferulic acid & $0.17 \pm 0.02^{g}$ & $10.91 \pm 0.57^{\mathrm{i}}$ & $\begin{array}{l}09.83 \pm \\
1.31^{\mathrm{i}}\end{array}$ & $33.04 \pm 0.81^{c}$ \\
\hline & $\begin{array}{l}\text { Caffeyol-D- } \\
\text { glucose }\end{array}$ & $3.24 \pm 0.02^{\mathrm{f}}$ & $3.45 \pm 0.03^{f}$ & $3.43 \pm 0.05^{f}$ & $34.11 \pm 0.46^{c}$ \\
\hline \multirow{2}{*}{ Chlorogenic acids } & Chlorogenic acid & nd & $2.50 \pm 0.01^{\mathrm{a}}$ & $10.74 \pm 0.02^{b}$ & $20.55 \pm 0.24 \mathrm{~g}$ \\
\hline & $\begin{array}{l}3-p \text { coumaroyl } \\
\text { quinic acid }\end{array}$ & $7.35 \pm 0.10^{\mathrm{d}}$ & $54.88 \pm 1.83^{\mathrm{j}}$ & $41.16 \pm 1.09^{\mathrm{k}}$ & $201.13 \pm 3.17^{\mathrm{h}}$ \\
\hline \multirow[t]{2}{*}{ Flavonoids } & Catechin & $3.33 \pm 0.02^{\mathrm{f}}$ & $3.60 \pm 0.05^{f}$ & $9.15 \pm 0.06^{\mathrm{i}}$ & $20.88 \pm 0.13 \mathrm{~g}$ \\
\hline & Gossypetin & $4.12 \pm 0.02^{c}$ & $32.97 \pm 1.77 \mathrm{~m}$ & $19.37 \pm 1.23^{\mathrm{e}}$ & $94.75 \pm 1.15^{n}$ \\
\hline
\end{tabular}

MeJA, methyl jasmonate; \pm S, standard error; nd, not detected; in the same column and on the same line, the means followed by the same letter are not significantly different (Duncan's test at 5\%); values represent the average of three repetitions

Table 3 Average contents of phenolic groups in cotton leaves treated with ethephon and co-treated with MeJA and ethephon

\begin{tabular}{|l|l|c|c|c|}
\hline \multirow{2}{*}{ Phenolic group } & \multicolumn{2}{|l|}{ Content $(\boldsymbol{\mu g} / \mathbf{g})$} & \multicolumn{2}{l|}{} \\
\cline { 2 - 5 } & $\begin{array}{l}\text { Control } \\
\text { not traited }\end{array}$ & MeJA (5 mM) & $\begin{array}{l}\text { Ethephon } \\
(5 \mathrm{~g} / \mathbf{l})\end{array}$ & $\begin{array}{l}\text { Cotraitement } \\
\text { MeJA/éthéphon }\end{array}$ \\
\hline Stilbenoids & $3.96 \pm 0.03^{\mathrm{a}}$ & $10.54 \pm 0.10^{\mathrm{b}}$ & nd & $83.60 \pm 0.08^{\mathrm{e}}$ \\
\hline Hydroxycinnamic acids & $3.41 \pm 0.03^{\mathrm{a}}$ & $17.83 \pm 0.11^{\mathrm{c}}$ & $13.26 \pm 0.15^{\mathrm{b}}$ & $84.40 \pm 0.15^{\mathrm{e}}$ \\
\hline Chlorogenic acids & $7.35 \pm 0.04^{\mathrm{d}}$ & $57.38 \pm 0.33^{\mathrm{f}}$ & $51.90 \pm 0.52^{\mathrm{f}}$ & $221.68 \pm 0.52^{\mathrm{g}}$ \\
\hline Flavonoids & $7.45 \pm 0.02^{\mathrm{d}}$ & $44.02 \pm 0.31^{\mathrm{h}}$ & $35.10 \pm 0.163^{\mathrm{a}}$ & $115.63 \pm 0.163^{\mathrm{b}}$ \\
\hline Terpenoids & $0.089 \pm 0.01^{\mathrm{c}}$ & $5.90 \pm 0.06^{\mathrm{d}}$ & $15.73 \pm 0.05^{\mathrm{b}}$ & $84.56 \pm 0.05^{\mathrm{e}}$ \\
\hline Phenolic pool $(\mu \mathrm{g} / \mathrm{g})$ & $22.26 \pm 0.05^{\mathrm{i}}$ & $135.67 \pm 0.21^{\mathrm{j}}$ & $115.99 \pm 0.18^{\mathrm{k}}$ & $589.87 \pm 0.18^{\mathrm{n}}$ \\
\hline
\end{tabular}

MeJA, methyl jasmonate; \pm S, standard error; nd, not detected; in the same column and on the same line, the means followed by the same letter are not significantly different (Duncan's test at 5\%); values represent the average of three repetitions. 
On the contrary, it would have a negative effect on the accumulation of hydroxycinnamic acids and flavonoids as well as the overall phenolic pool compared to MeJA (Table 3). It also seems to exert a total inhibition on the production of stilbenoids therefore biosynthetic enzymes of stilbenes like stilbene synthase. However, several studies have shown that stilbenes are involved in plant defenses by their ability to inhibit the germination of spores and the growth of fungi $[25 ; 26]$. Thus, our study clearly shows that the ethephon seems to activate the cotton's natural defenses less than the MeJA as already reported by Faurie et al [reference 27] in the vine.

In addition, the cotton leaves treated jointly with MeJA and ethephon enabled the biosynthesis of twelve phenolic compounds against ten for MeJA and seven for ethephon (Figure 1). However, the analysis of the phenolic profiles shows that trans-resveratrol and trans-picideide, two compounds belonging to the group of stilbenoids have been synthesized de novo by the joint application of MeJA and ethephon on the cotton leaves (figure 2).

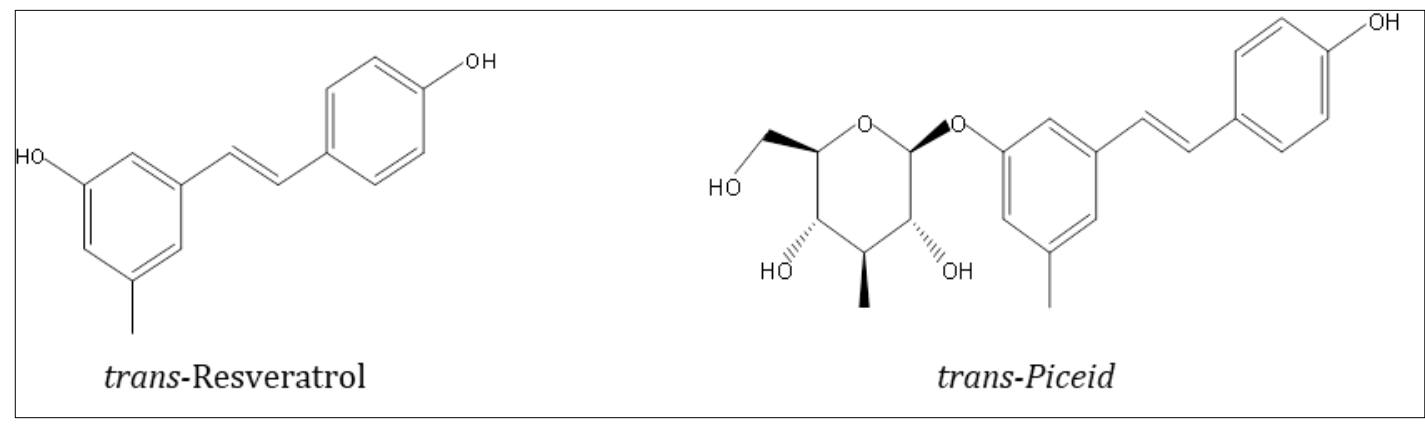

Figure 2 Chemical structure of trans-resveratrol and trans-piceid

These stilbenes could not be synthesized by the application of MeJA or ethephon alone. In addition, the co-treatment of the leaves with MeJA and ethylene allowed an exponential increase in the content of all the phenolic compounds synthesized compared to that obtained with MeJA or ethephon alone. Thus, the content of compounds such as ferulic acid, 3-p-coumaroylquinic acid and gossypetine increased by more than 3 times, trans-piceatannol by more than 4 times, catechin and chicoric acid by more 5 times, chlorogenic acid 8 times, caffeyol-D-glucose 10 times, gossypol 14 times and finally trans-pterostilbene 16 times compared to MeJA applied alone (Table 2). Likewise, the global phenolic pool which was $135.67 \mu \mathrm{g} / \mathrm{g}$ of leaves for MeJA increased and became four (4) times most important with the coinduction of leaves by the addition of MeJA and ethylene (Table 3). Thus, the concomitant application of MeJA and ethephon on the leaves therefore seems to have a supra-additive effect (synergy or potentiation) on the accumulation of phenolic compounds in cotton. This synergistic or cooperative effect of MeJA and ethephon on the biosynthesis of stilbenoids and the accumulation of phenolic compounds has also been reported in tobacco [28], Arabette [29;17] and the vine [30]. The gains in quantity of phenolic phytoalexins conferred by MeJA and ethephon separately are not total $(42.66 \%)$ (Table 4).

Table 4 Proportion of phenolic groups compared to the total phenolic pool of each type of cotton leaf treated by elicitors used alone or in combination

\begin{tabular}{|c|c|c|c|c|}
\hline \multirow[b]{2}{*}{ Phenolic group } & \multicolumn{4}{|c|}{ Proportion of phenolic content (\%) } \\
\hline & $\begin{array}{c}\text { Control } \\
\text { not traited }\end{array}$ & MeJA (5 mM) & $\begin{array}{c}\text { Etephon } \\
(5 \mathrm{~g} / \mathrm{l})\end{array}$ & $\begin{array}{c}\text { Cotraitment } \\
\text { MeJA/etephon }\end{array}$ \\
\hline Stilbenoids & $17.78 \pm 0.15^{\mathrm{a}}$ & $7.76 \pm 0.12^{b}$ & $0.00 \pm 0.00^{c}$ & $14.17 \pm 0.10^{\mathrm{a}}$ \\
\hline hydroxycinnamics acids & $15.31 \pm 0.13^{\mathrm{a}}$ & $13.14 \pm 0.17^{\mathrm{a}}$ & $11.43 \pm 0.20^{\mathrm{a}}$ & $14.30 \pm 0.20^{\mathrm{a}}$ \\
\hline Chlorogenic acids & $33.01 \pm 0.55^{\mathrm{d}}$ & $42.29 \pm 0.33^{\mathrm{e}}$ & $44.74 \pm 0.52^{\mathrm{e}}$ & $37.58 \pm 0.52^{\mathrm{d}}$ \\
\hline Flavonoids & $33.46 \pm 0.36^{d}$ & $32.44 \pm 0.29 \mathrm{~d}$ & $30.26 \pm 0.30^{\mathrm{d}}$ & $19.60 \pm 0.30^{a}$ \\
\hline Terpenoids & $0.39 \pm 0.02 \mathrm{~g}$ & $4.35 \pm 0.04 \mathrm{~g}$ & $13.56 \pm 0.02^{\mathrm{a}}$ & $14.33 \pm 0.02^{\mathrm{a}}$ \\
\hline
\end{tabular}

MeJA, methyl jasmonate; \pm S, standard error; nd, not detected; in the same column and on the same line, the means followed by the same letter are not significantly different (Duncan's test at 5\%); values represent the average of three repetitions.

The combination of the two elicitor molecules could increase the gains in resistance and protect the cotton plant against pathogens such as Fusarium oxysporum f. sp. vasinfectum. The MeJA and ethylene seem to fit into the complex cascade 
of cotton signals that lead it to mobilize its defenses. The addition of these elicitors would trigger stronger defense mechanisms than when used individually. Thus, a whole series of defense genes would then be induced and the defense responses put in place would lead to more efficient protection of the cotton plant against pathogens.

\section{Conclusion}

The results showed that ethephon, the metabolic precursor of ethylene, has properties identical to those of MeJA. Treating leaves with ethephon induces fewer phenolic compounds than MeJA. However, it stimulates the accumulation of chlorogenic acid, catechin and gossypol. Ethephon acts favorably on the accumulation of hydroxycinnamic acids and flavonoids as well as the total phenolic pool compared to MeJA. Ethephon acts favorably on the accumulation of hydroxycinnamic acids and flavonoids as well as the total phenolic pool compared to MeJA. It has an inhibitory effect on the biosynthesis of stilbenoids. Ethylene in the form of an ethephon thus exerts a weak activation of the cotton's natural defenses compared to MeJA. On the other hand, the treatment of the leaves with MeJA and the ethephon leads to an induction of phenolic compounds, which accumulate more important quantities in the plant. The phenols synthesized are more important with an activation of the biosynthetic pathway of stilbenoids because trans-resveratrol and transpiceide, two compounds belonging to the group of stilbenoids were synthesized de novo by the joint application of MeJA and ethephon on cotton leaves when they could not be synthesized when these two elicitors are applied alone. The addition of the phenolic pools conferred by the application of MeJA and ethephon separately represents only $42.66 \%$ of the phenolic pool obtained with the joint application of these two elicitors. The association MeJA / ethephon has a supraadditive effect on the accumulation of phenolic phytoalexins in cotton. Co-traitment of MeJA and ethephon therefore has a cooperative or synergistic effect on the production and accumulation of phenolic phytoalexins.

\section{Compliance with ethical standards}

\section{Acknowledgments}

The authors thank the "Groupe d'Etude des Substances Végétales à Activités Biologiques," Université Bordeaux 2 (France), for HPLC and NMR analyses.

\section{Disclosure of conflict of interest}

The authors declare that they have no conflict of interests regarding the publication of this paper.

\section{References}

[1] Assigbetse KB. Pouvoir pathogène et diversité génétique chez Fusarium oxysporum f. sp. vasinfectum (Atk) SN. Et H. : agent de la fusariose du cotonnier. Thèse de doctorat. Université de Monptellier II, Monpellier ; France. $1993 ; 158$.

[2] Belhadj A, Saigne C, Telef N, Cluzet S, Bouscaut J, Corio-Costet MF. Methyl jasmonate induces defense responses in grapevine and triggers protection against Erysiphe necator. Journal of Agricultur and Food Chemistry. 2006; 54(24): 9119-25.

[3] Belhadj A, Telef N, Cluzet S, Bouscaut J, Corio-Costet MF, Mérillon JM. Ethephon elicits protection against erysiphe necator in grapevine. Journal of Agriculturl and Food Chemistry. 2008; 56(14): 5781-5787.

[4] Benhamou N. Elicitor-induced plant defence pathways. Trends in Plant Science. 1996; 1: 233-240.

[5] CHARVET JP. « COTON », Encyclopædia Universalis [online], accessed April 10, 2020.

[6] Diaz J, Ten Have A, Van Kan JAL. The role of ethylene and wound signaling in resistance of tomato to Botrytis cinera. Plant Physiology. 2002; 129: 1341-135.

[7] Farmer EE, Alméras E, Krishnamurthy V. Jasmonates and related oxylipins in plant responses to pathogenesis and herbivory. Curr. Opin. Plant Biological. 2003; 6: 372-378.

[8] Faurie B, Cluzet S, Mérillon JM. Stimulation des défenses naturelles de la vigne, Vitis vinifera L., par le méthyle jasmonate et l'ethéphon. Etude de la voie de transduction du signal MeJA. Journée scientifique de l'école doctorale de l'Université Bordeaux 2, Arcachon. 2007. 
[9] Fontana A, Held M, Fantaye C, Turlings T, Degenhardt J, Gershenzon J. Attractiveness of Constitutive and Herbivore-Induced Sesquiterpene Blends of Maize to the Parasitic Wasp Cotesia marginiventris (Cresson). Journal of Chemical Ecology. 2011; 37(6): 582-591.

[10] Grayer RJ, Kokubun T. Plant fungal interactions: the search for phytoalexins and other antifungal compounds from higher plants. Phytochemistry. 2001; 56(3): 253-263.

[11] Hau B. Histoire de la sélection du cotonnier en Côte d'Ivoire. Coton et fibre Tropicales. 1988; 153(3): $177-193$.

[12] Heller W, Forkmann G. Biosynthesis of flavonoïde. In: Harborne, J.B., The flavonoïds Advance in Research since 1986, Ed. Chapman and Hall, Londres. 1993; 499-535.

[13] Legrand G. contribution à la caracterisation du métabolisme des acides chlorogeniques chez la chicorée. A pproches biochimiques et moléculaires. Thèse de doctorat à Université de Lilli 1 Sciences et technologies. 2015; 295.

[14] Konan YKF, Kouassi KM, Kouakou KL, Koffi E, Kouassi KN, Sékou D, Koné M, Kouakou TH. Effect of Methyl jasmonate on phytoalexins biosynthesis and induced disease resistance to Fusarium oxysporum f. sp. vasinfectum in Cotton (Gossypium hirsutum L.). International Journal of Agronomy. 2014; 102: 1-11.

[15] Kouakou TH, Kouadio YJ, Kouame P, Waffo Teguo P, Decendit A, Mérillon JM. Biochemical characterization of polyphenol oxydases extracted from embryogenic and non embryogenic cotton (Gossypium hirsutum L.) cells. Applied Biochemistry and Biotechnology. 2009; 158(2): 285-301.

[16] Kouakou TH. Contribution à l'étude de l'embryogénèse somatique chez le cotonnier (Gossypium hirsutum L.) : Evolution de quelques paramètres biochimiques au cours de la callogénèse et de cultures de suspensions cellulaires. Thèse de doctorat 3è cycle, Laboratoire de Physiologie Végétale, UFR Biosciences, Université de cocody, Abidjan Côte d'Ivoire. 2003; 137.

[17] Lambert C. Etude du rôle des stilbènes dans les defenses de la vigne maladie contre les maladies du bois. Thèse de doctorat de l'Université de Bordeaux 2, France. 2011; 179.

[18] Larronde F, Gaudillière JP, Krisa S, Decendit A, Deffieux G, Mérillon JM. Airborne methyl jasmonate induces stilbène accumulation in leaves and berries of grapevine plants. American. Journal of Enology and Viticulture. 2003; 54(1): 60-63.

[19] N'cho AL, Yapo SES, A L D G E, Kouakou TH. Impact of Elicitation by Methyl Jasmonate and Ethephon on Cotton (Gossypium hirsutum L.) Protection Against Fusarium Oxysporum F. Sp. Vasinfectum Journal of Advances in Agriculture. 2018; (9): 1559-1575.

[20] Opitz S, Kunert G, Gershenzon J. Increased Terpenoid Accumulation in Cotton (Gossypium hirsutum) Foliage is a General Wound Response. Journal of Chemical Ecology. 2008; 34: 508-522.

[21] Stafford HA. In: "chemistry and significance of condensed tannins", Ed Hemigway, R.W and Karchesy,J.J., New York. 1990; 47-70.

[22] Tamaoki M, Freeman JL, Pilon-Smits EA. Cooperative ethylene and jasmonic acid signaling regulates selenite resistance in arabidopsis. Plant Physiology. 2008; 146(3): 1219-30.

[23] Vessere RJ. Role of Peroxydase in cotton resistance to bacterial blight. Plant. Sci. Lett. 1990; 20: 47-56.

[24] Xu Y, chang PFL, Liu D, Narasimhan ML, Raghothama KG, Hasegawa PM, Bressan RA. Plant defense genes are synergistically induced by ethylene and methyl jasmonate. Plant Cell. 1994; 6: 1077-1085.

[25] Zeneli G, P Krokene E, Christiansen, Krekling T, Gershenzon J. Methyl jasmonate treatment of mature Nor-way spruce (Picea abies) trees increases the accumulation of terp-enoid resin components and protects against infection by Ceratocystis polonica, a bark beetle-associated fungus. Tree Physiology. 2006; 26: 977-988.

[26] Zhang PJ, Broekgaarden C, Zheng SJ, Snoeren TAL, VanLoon JJA, Gols R, Dicke M. Jasmonate and ethylene signaling mediate whitefly-induced interference with indirect plant defense in Arabidopsis thaliana. New Phytologist. 2013; 197(4): 1291-1299.

[27] Zhao J, Zheng SH, Fujita K, Sakai K. Jasmonate and ethylene signaling and their interaction are integral parts of the elicitor signalling pathway leading to betathujaplicin biosynthesis in Cupressus lusitanica cell cultures. Journal of Experimental Botany. 2004; 55(399): 1003-1015. 